\title{
Planning of labor resources in construction organizations
}

\author{
Zdzislaw Hejducki ${ }^{1}$, Anna Tzarenko ${ }^{2}$, Kamol Kamolov ${ }^{3}$, and Alexey Yurgaytis ${ }^{3, *}$ \\ ${ }^{1}$ Institute of Construction, Wroclaw University of Science and Technology, Wyb. Wyspia'nskiego \\ 27, 50-370 Wrocław, Poland \\ ${ }^{2}$ Department of Construction Management, Saint Petersburg State University of Architecture and Civil \\ Engineering (SPbGASU), 4 Vtoraya Krasnoarmeiskaya St., 190005, Saint Petersburg, Russian \\ Federation \\ ${ }^{3}$ Moscow State University of Civil Engineering, Yaroslavskoe shosse, 26, Moscow, 129337, Russia
}

\begin{abstract}
Based on the reporting and technical documentation and for the objects under consideration, the authors were able to form resource schedules that reflect the planned and actual values of the labor force for certain time periods. After analyzing the available statistics in terms of the activities of the leading production stream, a number of graphs were compiled showing the movement of these teams at the facilities. Based on these data, the authors determined the average deviation of the actual number of workers in the leading stream from the planned one. Also, the availability of operational information from these objects made it possible to determine the consequences of deviations and a set of measures taken. As a result, the authors analyzed the dynamics of construction of typical facilities of different general contracting organizations, taking into account the scale factor (capacity of the construction organization), indicating the difference in the values of the planned (predicted) and actual labor resources at the facilities. Possible solutions of this problem with the mathematical modeling of stable labor force distribution system at sites followed by a possible optimization of the objective function on limitations have been determined. Safe corridors of fluctuations in the values of the labor force, as well as the fundamental foundations of the optimization method, have been also determined.
\end{abstract}

\section{Introduction}

This article is devoted to the current production planning, which performs an important function at every stage of the construction project. A timely developed and optimized plan (production program) makes it possible to select effective organizational and technological solutions for the distribution of labor resources between program objects. The process of planning labor resources is considered on the example of 3 general contracting organizations. An important planning task is the harmonization of the values of the number of labor resources, given in the organizational and technological documentation, and the real

* Corresponding author: aljurgaitis@gmail.com 
capabilities of this construction organization, taking into account the actual production situation at the program facilities [1-5]. A serious destabilizing factor in this regard is the need to interconnect the totality of objects of the annual (or two-year) program of the construction organization, since planning departments have to ensure the implementation of the whole portfolio of construction projects, while ensuring the most complete and even load of the organization's internal resources (labor resource and construction machinery park) [1 5]. However, today the planning system of most construction organizations is not able to provide rational planning of the labor for the objects of the program, taking into account the existing destabilizing factors and effective optimization techniques for the dynamic redistribution of resources between objects, if necessary [7].

\section{Materials and Methods}

To analyze the actual situation on construction sites, a statistical study of the results of planning the movement of workers was carried out to establish deviations from the planned values. In this article, for example, data are given for three general contractors. Tables 1 - 3 provide general data on the organizations and facilities under consideration, as well as the construction time and area of the facilities under consideration.

Table 1. Description of the organizations under consideration.

\begin{tabular}{|c|c|c|}
\hline № & Characteristic & Value \\
\hline 1 & Capacity & Large and medium \\
\hline 2 & Leading work process & The device of monolithic structures \\
\hline 3 & Status of organization & General contractor \\
\hline
\end{tabular}

Table 2. Description of the objects under consideration.

\begin{tabular}{|c|c|c|}
\hline № & Characteristic & Value \\
\hline 1 & Structural diagram & Monolithic frame \\
\hline 2 & Location & Moscow and Moscow region \\
\hline 3 & Functional purpose & Residential \\
\hline 4 & Number of storeys & From 3 floors \\
\hline
\end{tabular}

Table 3. Summary table of properties of the investigated objects of general contractors

\begin{tabular}{|l|l|l|l|}
\hline \multicolumn{5}{|c|}{ General contractor №1 } \\
\hline An object & Total area, $\mathbf{~ m}^{\mathbf{2}}$ & $\begin{array}{l}\text { Beginning of } \\
\text { work }\end{array}$ & $\begin{array}{l}\text { Completion of } \\
\text { work }\end{array}$ \\
\hline Complex 1 & 146214 & january 2015 & july 2018 \\
\hline Complex 2 & 134378 & january 2017 & Mapt 2019 \\
\hline Complex 3 & 99062 & january 2017 & June 2018 \\
\hline \multicolumn{5}{|c|}{ General contractor №2 } \\
\hline Complex 1 & 135305 & january 2018 & 2019 \\
\hline
\end{tabular}




\begin{tabular}{|l|l|l|l|}
\hline Complex 2 & 106598 & June 2018 & 2020 \\
\hline Complex 3 & 238824 & april 2018 & 2020 \\
\hline \multicolumn{5}{|c|}{ General contractor №3 } \\
\hline Complex 1 & 89999 & april 2018 & 2020 \\
\hline Complex 2 & 63500 & november 2017 & 2019 \\
\hline Complex 3 & 97675 & january 2018 & 2020 \\
\hline
\end{tabular}

The graphs ( Figure $1-3$ ) provide summary data on the distribution of labor at the facilities of the production program of the corresponding general contractor. The values of the planned number and the actual number of workers in the leading stream for the installation of monolithic reinforced concrete structures at the corresponding stages of the construction of facilities are given. The fluctuation in values was caused by the influence of a set of destabilizing production factors at specific construction sites.

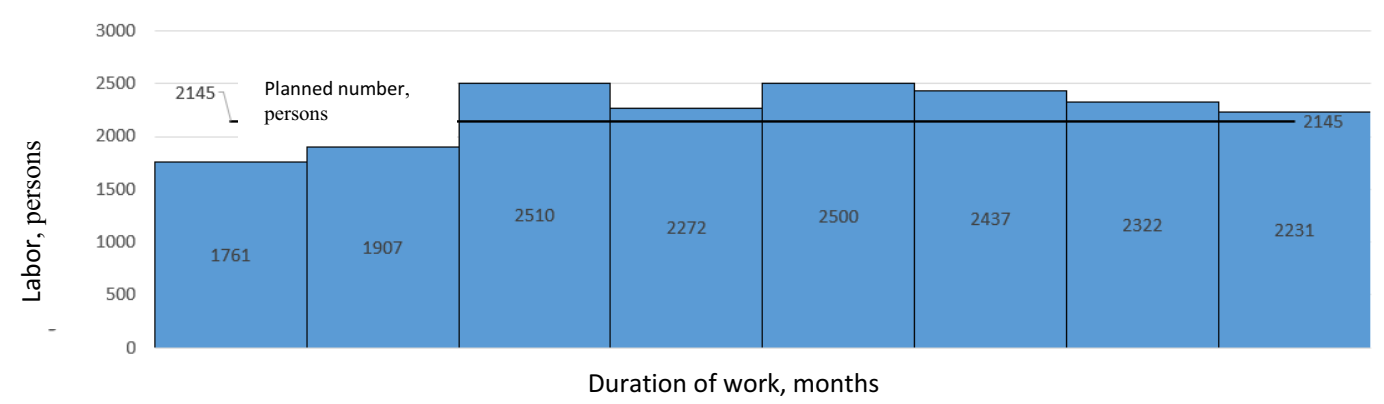

Fig. 1. Sum general contractor 1

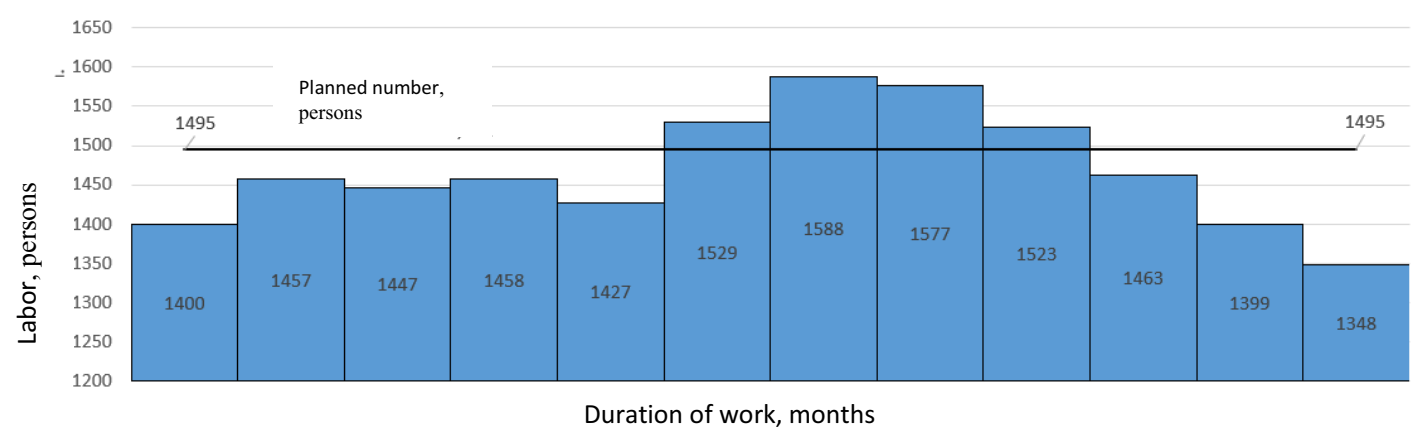

Fig. 2. Sum general contractor 2 


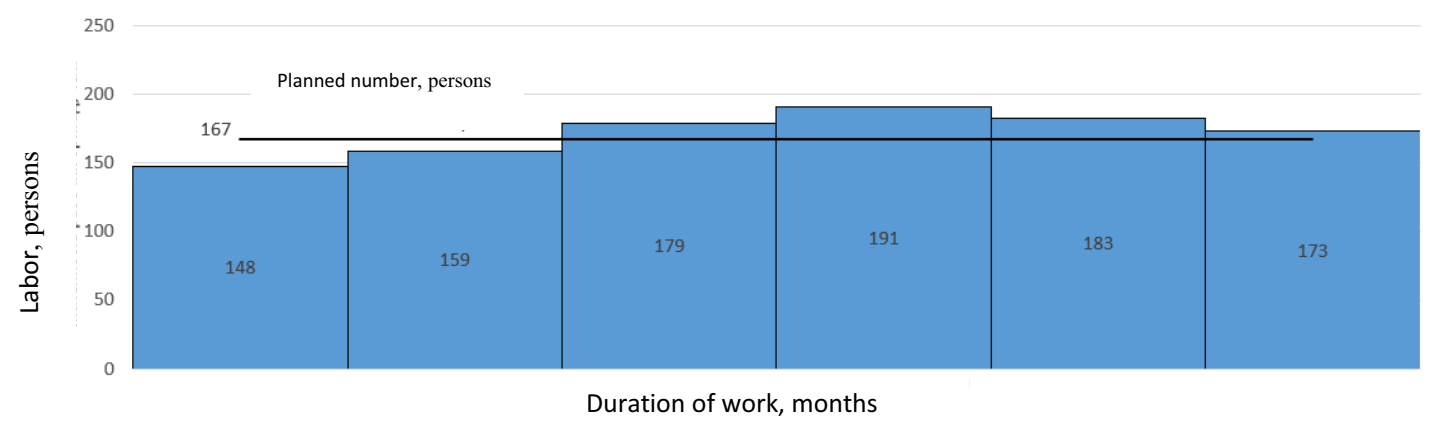

Fig. 3. Sum general contractor 3

After proper processing of the obtained empirical data of the experiment, the following summary table can be drawn up, showing the average value of fluctuations in the number of workers in the leading production stream (table 4).

Table 4. Analysis of deviation of the actual number of monoliths from the planned one

\begin{tabular}{|c|c|c|}
\hline \multirow{2}{*}{ Organization number } & Object number & $\begin{array}{c}\text { Average deviation of the } \\
\text { actual labor force from the } \\
\text { planned } \mathbf{\%}\end{array}$ \\
\hline \multirow{3}{*}{ General contractor 1 } & Object 1 & 10,7 \\
\cline { 2 - 3 } & Object 2 & 2,5 \\
\cline { 2 - 3 } General contractor 2 & Object 3 & 0,6 \\
\cline { 2 - 3 } & Object 1 & 0,5 \\
\cline { 2 - 3 } & Object 2 & 3,4 \\
\hline \multirow{3}{*}{ General contractor 3 } & Object 3 & 2,5 \\
\cline { 2 - 3 } & Object 1 & 0,9 \\
\cline { 2 - 3 } & Object 2 & 0 \\
\hline
\end{tabular}

This study makes it possible to make a significant contribution to the theory of optimization of schedules and work plans of production programs of construction organizations. Many scientists have dealt with such issues in their scientific works [1-23], however, on the basis of the data obtained, it becomes possible to identify the corridors of safe fluctuations in the size of the labor force at the facility, which do not require fundamental optimization actions. As the analysis of the above large and medium-sized objects has shown, such fluctuations can be leveled out due to the internal reserves of production units, as well as through the use of an effective organizational model using the bases of the construction industry.

By purposefully bringing together the values of the planned and actual allocation of resources, a condition can be formed for the balance of the work plan of the production program in terms of the number of labor resources relative to the actual, dynamically changing production situation at a private facility (formula 1). In this case, the objective function (formula 2) in the ideal case turns to zero, but in practice the difference between the planned and actual values of the labor force will be nonzero. The objective function constraints are shown in Table 5. 


$$
\begin{gathered}
\sum_{i=1}^{n}\left[R^{i} \cdot\left(t_{k+1}^{i}-t_{k}^{i}\right)+\Delta R^{i} \cdot\left(t_{k+1}^{i}-t_{k}^{i}\right)\right]=\sum_{i=1}^{n}\left[R_{f}^{i} \cdot\left(t_{k+1}^{i}-t_{k}^{i}\right)\right] \\
S=f(R)=\sum_{1}^{n} R_{f a c t}-R_{p l} \rightarrow \min
\end{gathered}
$$

Where $i=\overline{1 ; n}-$ is the serial number of the object of the production program of the construction organization;

$n$ - the number of objects of the production program of the construction organization in the range $n \in[1 ; n]$ [array of natural numbers];

$R^{i}$ - the planned number of labor resources of the leading stream for the installation of monolithic reinforced concrete structures (critical work) for the i - object, [people];

$\Delta R^{i}$ - an increase in the labor resource (planned number) of the leading stream for the installation of monolithic reinforced concrete structures (critical work) for the i - object due to the influence of a set of factors of the production program [people];

$t_{k}^{i}$ - the estimated time period for an elementary container of a resource on the labor force movement diagram for $i$ - the object [days];

$R_{f}^{i}$ - the actual number of labor resources of the leading stream for the installation of monolithic reinforced concrete structures (critical work) for the i-object, [people].

Table 5. Limitations of the objective function (criteria for verifying the generated variants

\begin{tabular}{|c|c|c|c|}
\hline № & $\begin{array}{l}\text { Objective function limitation } \\
\text { and its description }\end{array}$ & $\begin{array}{c}\text { Restriction } \\
\text { notation }\end{array}$ & $\begin{array}{c}\text { Mathematical } \\
\text { description and } \\
\text { calculation features }\end{array}$ \\
\hline \multicolumn{4}{|c|}{ The main } \\
\hline 1. & $\begin{array}{l}\text { The limitation of the maximum } \\
\text { possible actual number of } \\
\text { workers in production } \\
\text { departments is due to the mode of } \\
\text { use of the labor resource for a } \\
\text { specific section of the integral } \\
\text { diagram, which, in the general } \\
\text { case, cannot exceed the available } \\
\text { initial capacity of the } \\
\text { construction organization (the } \\
\text { staff number of workers in the } \\
\text { leading production process) }\end{array}$ & $R_{\max }$ & $\begin{array}{l}\qquad R^{i}+\Delta R^{i} \leq R_{\max } \\
\text { The numerical value is } \\
\text { set by the planning } \\
\text { operator based on the } \\
\text { received initial data on } \\
\text { the initial capacity of the } \\
\text { construction organization } \\
\text { (the number of staff in } \\
\text { the leading production } \\
\text { process) }\end{array}$ \\
\hline 2. & $\begin{array}{l}\text { Restriction of the physical area of } \\
\text { the workplace of the work front } \\
\text { of the production unit - saturation } \\
\text { of the work front should be made } \\
\text { from the condition of the rational } \\
\text { organization of the workplace of } \\
\text { a separate link of performers to } \\
\text { prevent a sharp decrease in the } \\
\text { output of individual workers due }\end{array}$ & $R_{\text {lim }}$ & $\begin{array}{l}\qquad R^{i}+\Delta R^{i} \leq R_{\text {lim }} \\
\text { The numerical value is } \\
\text { set by the planning } \\
\text { operator based on the } \\
\text { maximum possible } \\
\text { number of workers per } \\
1 \mathrm{~m} 2 \text { of the allocated }\end{array}$ \\
\hline
\end{tabular}
of the distribution of production units by program objects) 


\begin{tabular}{|c|c|c|c|}
\hline № & $\begin{array}{l}\text { Objective function limitation } \\
\text { and its description }\end{array}$ & $\begin{array}{l}\text { Restriction } \\
\text { notation }\end{array}$ & $\begin{array}{c}\text { Mathematical } \\
\text { description and } \\
\text { calculation features }\end{array}$ \\
\hline & $\begin{array}{c}\text { to the violation of the ergonomics } \\
\text { of construction production }\end{array}$ & & $\begin{array}{l}\text { work front at the } \\
\text { program facility }\end{array}$ \\
\hline 3. & $\begin{array}{l}\text { Limiting the minimum number of } \\
\text { workers at the facility } \\
\text { (Minimum composition of a } \\
\text { specialized labor) }\end{array}$ & $R_{\min }$ & $\begin{array}{l}R^{i}+\Delta R^{i} \geq R_{\min } \geq 0 \\
\text { It is determined from the } \\
\text { conditions for the } \\
\text { fulfillment of the } \\
\text { construction contract, the } \\
\text { conditions for the } \\
\text { preparation of the work } \\
\text { front for related } \\
\text { divisions, or the } \\
\text { conditions for } \\
\text { maintaining the planned } \\
\text { level of productivity of } \\
\text { work at a specific object } \\
\text { of the program. }\end{array}$ \\
\hline 4. & $\begin{array}{l}\text { Deadline for the completion of } \\
\text { work (delivery of the object) } \\
\text { (mainly for general contractors) }\end{array}$ & $T_{\text {dir }}$ & $\begin{array}{c}\sum_{i=1}^{n} T_{i}^{p l} \leq T_{d i r} \\
\frac{T_{i}^{p l}}{t_{k}^{i}}=k \\
t_{k}^{i} \in T_{i}^{p l}\end{array}$ \\
\hline 5. & Critical path (lead time) & $T_{c r}$ & $\begin{array}{c}\sum_{i=1}^{n} T_{i}^{p l} \leq T_{c r} \\
\frac{T_{i}^{p l}}{t_{k}^{i}}=k \\
t_{k}^{i} \in T_{i}^{p l}\end{array}$ \\
\hline \multicolumn{4}{|c|}{ Additional (Optional) } \\
\hline 6. & $\begin{array}{l}\text { The total distance of relocation } \\
\text { of working personnel between } \\
\text { objects in accordance with the } \\
\text { cartogram }\end{array}$ & $L_{\text {lim }}$ & $\begin{array}{l}\text { Determined by the } \\
\text { planning operator } \\
\text { according to the } \\
\text { relocation cartogram of } \\
\text { the labor resource }\end{array}$ \\
\hline 7. & $\begin{array}{l}\text { The total cost of relocation of } \\
\text { workers between objects in } \\
\text { accordance with the cartogram }\end{array}$ & $\mathrm{C}_{l}$ & - \\
\hline 8. & $\begin{array}{l}\text { Limitation on the number of } \\
\text { production units for non-critical } \\
\text { work (in the case of concluding a } \\
\text { general contract for a set of works } \\
\text { or the presence of a certain } \\
\text { number of managed } \\
\text { subcontractors and the need to }\end{array}$ & $r_{\max }$ & $\begin{array}{l}\qquad r^{i}+\Delta r^{i} \leq r_{\max } \\
\quad r^{i}+\Delta r^{i} \geq 0, \\
r_{\max }-\text { is the maximum } \\
\text { ability of the } \\
\text { subcontractor to provide } \\
\text { related non-critical work } \\
\text { by production units (this }\end{array}$ \\
\hline
\end{tabular}




\begin{tabular}{|c|l|l|l|}
\hline № & $\begin{array}{l}\text { Objective function limitation } \\
\text { and its description }\end{array}$ & $\begin{array}{c}\text { Restriction } \\
\text { notation }\end{array}$ & $\begin{array}{c}\text { Mathematical } \\
\text { description and } \\
\text { calculation features }\end{array}$ \\
\hline $\begin{array}{l}\text { take into account non-critical, } \\
\text { related works) }\end{array}$ & $\begin{array}{l}\text { number is provided by the } \\
\text { corresponding number of } \\
\text { the construction control } \\
\text { apparatus of the } \\
\text { contractor) }\end{array}$ \\
\hline
\end{tabular}

\section{Results and Discussion}

In the process of analyzing the work of contractors for the installation of monolithic reinforced concrete structures, the expected deviation of the number of labor resources relative to the planned indicators was revealed. Moreover, this percentage fluctuates within a certain limit. Based on additional statistical justification, it is possible to derive the optimal threshold for the deviation of the actual power from the estimated number of work teams. In this case, the practice of implementing construction projects proves that there is no need to optimize actions in relation to the objects of production programs, since these fluctuations can be leveled out by the internal production reserves of large organizations (Figure 4). Taking into account such safe fluctuation corridors in automated planning and periodic optimization of labor force movement schedules using various software systems makes it possible to somewhat expand the range of decisions made. Thus, large organizations usually have a logistics base in their organizational structure, on which the freed up labor force reserves are concentrated (Figure 5). Such reserves cover the need for resources in the event of a spontaneously arising need (labor shortage, for example, due to diseases, epidemics, suddenly added volumes of work and objects to the production program).

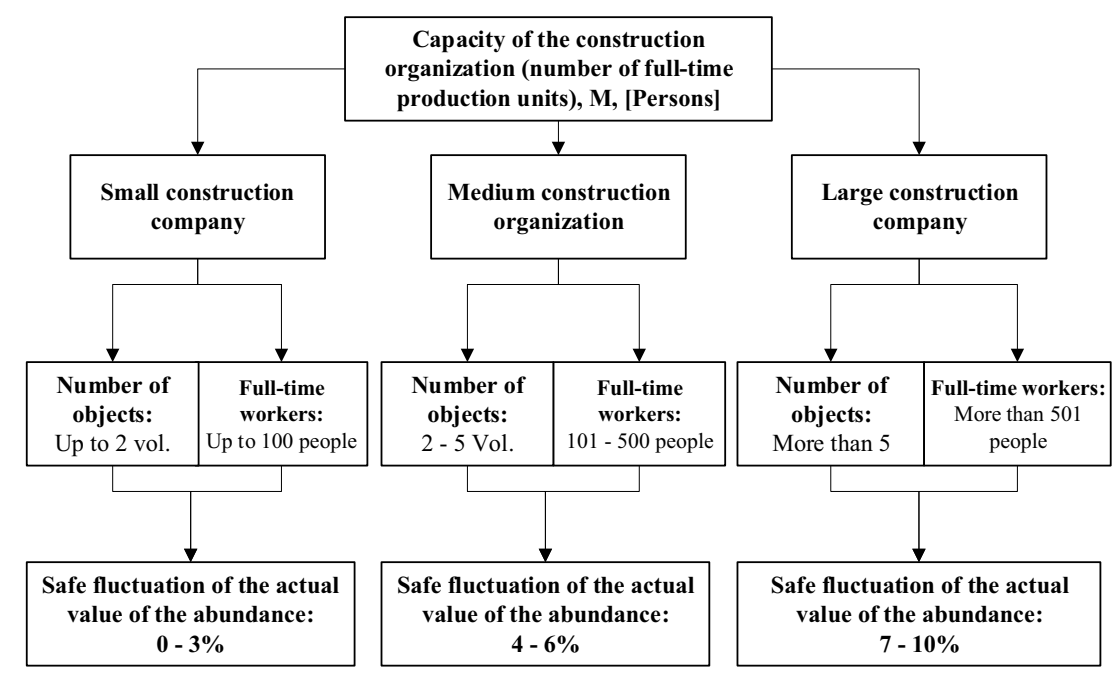

Fig. 4. The final scheme, taking into account the corridors of safe fluctuations for construction organizations of various production capacities (this article provides statistics only for large and medium-sized organizations). Corridors of values are given taking into account the safety factor 


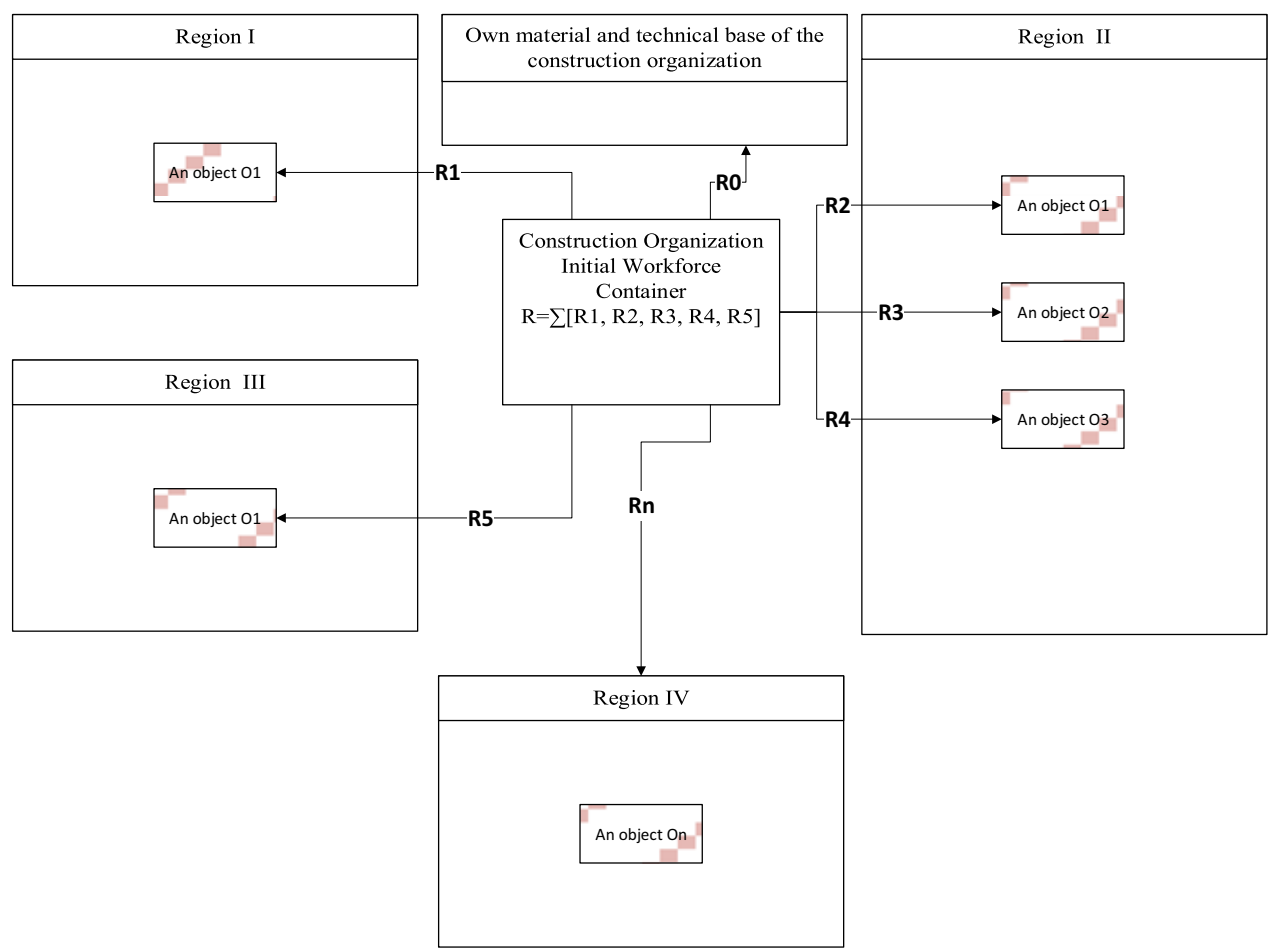

Fig. 5. The topology of the distributed objects of the production program - with the help of large construction organizations. The case of vacated units (labor buffer) employed on their own logistics base

\section{Conclusions}

Now there are several problems that arise in the planning of labor:

- urgent needs of the $\mathrm{s}$ in a formalized universal method of calculation of the size and composition of a qualified work force to an object,

- the emergence of uncontrolled fluctuations in the number of labor resources under the influence of destabilizing factors.

The existing problems, in turn, lead to the irrelevance of the calculated values, the complexity of the contractor in the formation of organizational and technological documentation, the spontaneous relocation of resources between objects and works in case of such a need, a decrease in the productivity of workers, as well as suboptimal workload of production units. The development of a comprehensive methodology for the formation and optimization of the production program, taking into account the safe tolerances of fluctuations of the resource field, solves a number of the listed problems in planning the workforce. In this case, the optimization mechanism acquires system properties:

- the objective function and restrictions allow to stabilize the planning system by balancing resource consumption relative to the planned values;

- depending on the capacity of the organization and its organizational structure, rational decisions on the movement of workers can be pre-formed (use of the material and technical supply bases of large organizations);

- the optimization model uses the calculated safe fluctuations in the values of the labor force at the objects of the program. 
This methodology for the formation and optimization of the work plan for the workload of labor relative to the planned values significantly speeds up the process of current planning and the process of forming managerial decisions by the planning operator.

\section{References}

1. P. Oleinik, A. Yurgaytis, MATEC Web of Conferences, 117, 00130, (2017), https://doi.org/10.1051/matecconf/201711700130

2. D. Topchiy, A. Shatrova, A. Yurgaytis, MATEC Web of Conferences, 193, 05032, (2018), https://doi.org/10.1051/matecconf/201819305032

3. P. Oleinik, A. Yurgaytis, MATEC Web of Conferences, 193, 05010, (2018), https://doi.org/10.1051/matecconf/201819305010

4. P. Oleinik, A. Yurgaytis, G. Voronina, A. Makarenko, MATEC Web of Conferences, 251, 05037 (2018), https://doi.org/10.1051/matecconf/201825105037

5. P. Oleinik, A. Yurgaytis, MATEC Web of Conferences 265, 07024 (2019), https://doi.org/10.1051/matecconf/201926507024

6. V.Chulkov, A. Yurgaytis, E3S Web of Conferences 164, 10032 (2020), https://doi.org/10.1051/e3sconf /202016410032

7. P. Oleinik, A. Yurgaytis, E3S Web of Conferences 175, 11016 (2020), https://doi.org/10.1051/e3sconf/202017511016

8. A Tzarenko, A Yurgaytis, IOP Conf. Series: Materials Science and Engineering $\mathbf{7 5 3}$ (2020) 032072, doi:10.1088/1757-899X/753/3/032072

9. P. Oleinik, A. Yurgaytis, IOP Conf. Series: Materials Science and Engineering $\mathbf{7 5 3}$ (2020) 032077, doi:10.1088/1757-899X/753/3/032077

10. M. Rogalska, W. Bozejko, Z. Hejducki, Automation in Construction, 18, 24-31, (2008), doi:10.1016/j.autcon.2008.04.002

11. W. Bozejko, Z. Hejducki, M. Uchroński, M. Wodecki, Journal of Civil Engineering and Management, 20, (2014), DOI: 10.3846/13923730.2014.906496

12. W. Bozejko, Z. Hejducki, M. Wodecki, Journal of Civil Engineering and Management, 18 (5), 621-630, (2012)

13. M. Rogalska, W. Bozejko, Z. Hejducki, M. Wodecki, Development of time couplings method using evolutionary algorithms, ISARC 2008 - Proceedings from the 25th International Symposium on Automation and Robotics in Construction (2008)

14. M. Uchroński, W. Bożejko, Z. Krajewski, M. Tykierko, M. Wodecki, International Conference on Dependability and Complex Systems, 1, 504-514 (2018)

15. W. Bożejko, A. Gnatowski, J. Pempera, M. Wodecki, Computers \& Industrial Engineering, 113, 512-524, (2017)

16. M. Walczyński, W. Bożejko, D. Skorupka, AIP Conference Proceedings, 1863 (1), 230014, (2017)

17. W. Bożejko, J. Pempera, M. Wodecki, Archives of Control Sciences, 27 (2), 169-181, (2017)

18. Barrie, D. S. and B. C. Paulson. 1992. Professional Construction Management. 3rd ed. New York: McGraw-Hill. 
19. Bennett, F. L. 2003. The Management of Construction: A Project Life Cycle Approach. Boston: Butterworth-Heinemann.

20. Certo, S. C. 2008. Modern Management. 11th ed. Upper Saddle River, NJ: Prentice Hall.

21. Clough, R. H., G. A. Sears, and S. K. Sears. 2008. Construction Project Management: A Practical Guide to Field Construction Management. 5th ed. Hoboken, NJ: Wiley.

22. Collier, K. 1994. Managing Construction: The Contractual Viewpoint. Albany, NY: Delmar.

23. De Soto, B.G., Rosarius, A., Rieger, J., Chen, Q., Adey, B.T.: Using a Tabu-search Algorithm and 4D Models to Improve Construction Project Schedules, Procedia Engineering, 196 (2017), pp. 698- 705. 